\title{
introduction \\ tensions of empire: colonial control and visions of rule
}

\author{
FREDERICK COOPER-University of Michigan, Department of History \\ ANN L. STOLER-University of Michigan, Department of Anthropology
}

The papers in this volume were first presented to a Wenner-Gren Foundation conference held in Mijas, Spain, in November 1988. A roughly equal number of historians and anthropologists with different regional expertise were invited to rethink what frameworks and themes the anthropology of colonialism should entail.' Our goal was to bring metropole and colony into a single analytic field, overcoming the tendency of the one to go out of focus as the other comes in. We hoped to maintain a global perspective while probing the more intimate reaches of colonial power relations at the same time.

Anthropologists have been most concerned with the consequences of conquest for the colonized and its impact on indigenous social and economic organization. Despite anthropology's successful efforts to move away from the isolated community studies of earlier generations, we still tend to treat colonialism as an abstract process, and focus more on the agency of those subject to colonial rule than on the agency of those who carried it out. For their part, historians of Africa and Asia have, since the 1960s, tried to distance themselves from the assumptions of an earlier tradition of imperial history, seeking to establish the integrity and dynamics of nonWestern societies and the complexity of their reactions to European political and economic dominance. Neither discipline has explored deeply how the rulers of empire reexamined their own hegemony in the face of the divisions within their own camp and the challenges from the people they were trying to rule. In refocusing the attention of the conference on the tensions among colonizers and between them and the colonized, we began from the premise that even these categories were not fixed but problematic, contested, and changing.

Colonial regimes were neither monolithic nor omnipotent. Against the power which they projected across the globe and against their claim to racial, cultural, or technological dominance, closer investigation reveals competing agendas for using power, competing strategies for maintaining control, and doubts about the legitimacy of the venture. It is not clear that the idea of ruling an empire captivated European publics for more than brief periods, or that a coherent set of agendas and strategies for rule was convincing to a broad metropolitan population, any more than the terms in which regimes articulated their power inspired awe or conviction among a broad range of the colonized.

Although the agents of colonization-officials, missionaries, and entrepreneurs-possessed seemingly immense culture-defining capacity, more and more evidence is emerging of the anxiety of colonizers lest tensions among themselves over class, gender, and competing visions of the kind of colonialism they wished to build fracture the facade. Scholars are uncovering conflicting conceptions of morality and progress, which shaped formal debates as well as subterranean discourses among high and low-level officials, technical specialists, planters, farmers, merchants, missionaries, and subordinate agents of corporations, among poor whites, people of mixed origins, and other interstitial groups.

How categories were constructed, how cultural boundaries were maintained, allowed for specific forms of violence at specific times. Identifying the competing agendas of colonizers is 
not an academic exercise in historical refinement: it should allow us to see how political weight shifted and how the contradictions these tensions engendered opened possibilities for empowerment among the colonized. The idea of an indigenous "response" or "resistance" to an imperialist initiative no longer captures the dynamics of either side of the encounter.

Once the talking began, all of us_historians and anthropologists, specialists on Africa, India, Southeast Asia, the Middle East, and the Americas_found ourselves plunged into an even more basic discussion than the organizers had envisioned. We had hoped, for example, that by limiting our chronological focus to the era of developing capitalism and the modern European state, we could tightly compare and periodize different discourses on colonial society, among different sorts of colonial "experts," among missionaries, settlers, and bureaucrats, and in relation to varying forms of colonial penetration and differing dynamics of indigenous societies. The possibility of such limitations, even for purposes of focusing discussion, was vigorously debated: as Sidney Mintz pointed out, one of the most obviously modern and most obviously capitalist institutions-factory-like production with a large body of workers-did not originate in Europe with the development of capitalism, but in the West Indies with the development of plantation slavery. Some even wanted to question the distinctiveness of a domain that could be called colonial. Jacques Marseille pointed out that bourgeois Frenchmen at the very end of the 19th century could refer to provincial villagers in similar terms to those used by colonial officials to describe the people of Central Africa, and he questioned the extent to which the pair colonizer/colonized could be separated from the oppositions of class and region in metropolitan societies. For other participants, the parallel between these hierarchies was metaphorical, and the nature of coercion and the definition of group boundaries in metropolitan and colonial situations was fundamentally different. A spectrum of opinion on the specificity of the colonial emerged from discussions. Related to this was a series of questions about the historical connections of power and inequality in metropole and colony: in what ways did European class politics provide models for colonial racial policy, how were metropolitan class visions transformed on colonial ground, and how in turn did the encounter with the colonized transform the meaning of class and other distinctions among the agents of colonization?

Here lies a basic tension of empire: the otherness of the colonized person was neither inherent nor stable; his or her difference had to be defined and maintained; social boundaries that were at one point clear would not necessarily remain so. To the extent that colonial states pursued a "civilizing mission" - or to the extent to which they tried to make colonial peoples into disciplined agriculturalists or workers and obedient subjects of a bureaucratic state-they opened up a discourse on the question of whether still more "civilizing" would make them into still better farmers, workers, or subjects-and hence a less distinctive category of being. To the extent that European officials, settlers, and traders interacted sexually with colonized women, they threatened "racial purity" and opened up questions about the clarity of the cultural conventions that secured male white supremacy through distinctions of class, race and gender (see Stoler, this volume). Such questions could-and in fact did-force colonial regimes to ponder just who should be in the colonies, how long they might stay, where and with whom they might live.

Not all of these questions were new in 19th-century colonialism. But the ideological terms in which European leaders projected their imperialism - to each other, to the domestic polity, and to some extent to their subject peoples-did change in conjunction with the metropolitan politics of nationhood, the redefinition of citizenship in the European nation-state, the spreading web of capitalist relations of production and of exchange, and the universalistic language of post-Enlightenment thought. From that point onward, the necessarily particularistic nature of colonization-defining an exclusive and coercive relationship between the colony and a single dominant state-existed in profound tension with universalistic discourse emanating from Europe on questions of economic rationality, personhood, freedom, participation, and social progress. It became possible to talk in abstract terms, about land and labor, class and 
race, across the boundaries of religion and nation, even if struggles over land, labor, class, and race could not be separated from their local contexts and long histories.

If, at any one moment, one could plausibly argue that the attitudes and policies of a metropolitan ruling class toward lower classes, local speech, and regional social practices were comparable to attitudes and policies toward colonized people, the specificity of the colonial domain emerged over time: the dialectics of domination, incorporation and differentiation were played out in the colonies in a form in which racial distinction was an organizing principle and a powerful rhetorical theme. ${ }^{2}$ The 19 th century, when European bourgeoisies were accumulating capital and defining their own social identity, was also a time when European states were crystalizing and incorporating the masses within them into some form of citizenship and participation in a collectivity. The late 19th-century wave of conquest of alien peoples and the maintenance and reinforcement of their distinctiveness occurred in this metropolitan context. In both metropole and the colonies, the basic categories of discourse-including the very meaning of colonizer and colonized-were conceptualized and contested in biological, cultural, and sexual terms. ${ }^{3}$

This tension between the particularism of European colonial rule and the universalism of European ideology would remain fundamental. It is far more complicated than the age-old separation of lofty ideals and sordid practices; ideals and practices were both changing in relation to one another and could not be separated from the challenges of the colonized.

The conference papers and discussions can be grouped into three broad topics: knowledge and rule; the politics of reproduction; and problems of periodization.

\section{knowledge and rule}

Bernard Cohn began the discussion of knowledge and rule by emphasizing the conscious way in which a model colonial regime-the Raj-went about creating the categories in which the British and Indians were to define themselves. A large colonial bureaucracy occupied itself, especially from the 1860s, with classifying people and their attributes, with censuses, surveys, and ethnographies, with recording transactions, marking space, establishing routines, and standardizing practices. The total effect exceeded the sum of each appropriation of information: colonial regimes were trying to define the constituents of a certain kind of civil society, even as they hid the act of creation beneath the idea that society was a natural occurrence and the state a neutral observer and regulator. Self-conscious projects of collecting and organizing knowledge-including censuses, surveys, and land settlements-were applied, according to Scott Atran, as a virtual package when the British took over the Palestinian mandate in 1920; they were applied less systematically in much of Africa. The visual world could be tamed as well; David Prochaska's paper on postcards from French Algeria revealed how a distinctly colonial subject emerged from pictures that framed indigenous people engaged in what seemed like characteristic sorts of activities.

Such considerations led conference participants to ask to what extent-and by what processes-the knowledge of individual empires became a collective imperial knowledge, shared among colonizing powers. Was there ever a language of domination, crossing the distinct metropolitan polities and linguistic barriers of French, English, Spanish, German, and Dutch, and common models of how to constitute an empire?

Visions of empire were created and clarified out of metropolitan discourses as well as by those fashioned in the colonies themselves. The relationship among social darwinism, ethnology and colonial projects, for example, has been the most extensively and carefully explored. Other academic and popular discussions have received less attention. The class politics of Europe in the late 19th century gave rise to a profusion of debates by scientists, social reformers, and state agents over the biological and moral nature of the rapidly expanding European work- 
ing-class populations. As elites worried over the political mobilization of the underclasses, so did the bourgeoisie obsess over the forms of family organization, sexual standards, medical care, and moral instruction by which they would safeguard their property and profits and reproduce the social structure. How did these discourses translate in the colonies, affecting such questions as the spatial distribution of the races in colonial cities? What are the ways in which class visions were transformed into racial distinctions on colonial ground?

Nineteenth century discussions of Africans and Asians were replete with biological metaphors; but biological and medical science provided more than metaphors for colonial domination. They provided the proof and rationalization for European supremacy as it was played out in racial terms. Part of the scholar's task is to analyze how the debates and terminologies of medicine, urban planning, social welfare, and industrial relations fed off one another and borrowed one another's idioms, without assuming that they were functionally compatible or that they reinforced imperial policy in all places and at all times.

On the contrary: Randall Packard's paper illustrates the contradictions within a conception of scientific knowledge that portrayed itself as apolitical. The South African medical establishment became particularly invested in the idea of the "healthy reserve"-a space where Africans could recover in their "natural" environment and free themselves of the diseases acquired in their sojourns to industrial space-at precisely the times, the 1920s and again in the 1950s, when agricultural experts were warning that conditions in the reserves were taking decisive turns to the worse.

Some metropolitan discourses resonated in the colonies; others did not. Debates over the reproductive advantages of miscegenation, for example, never surfaced as did the contrary theories that argued that racial mixing would result in the degeneration and disappearance of the white populations on which empires rested. The interesting question is how much the racist tendencies in medical science, and eugenics in particular, received new credibility in the colonies and then reverberated at home.

How European scientific knowledge would be used in colonial contexts is not self-evident. Similarly, who had what visions of empire cannot be assumed. Scott Atran's paper, as well as Jacques Marseille's, showed how leftist Zionists, like leading French socialists, justified the taking and holding of colonies in light of their vision of a just, socialist society, and their claim to knowledge of the path to reach it-a path that indigenous peoples, lost in their primitive or precapitalist worlds, could not otherwise follow. Still, certain relativist social theories-arguments that each people has its own integrity and its own path to the future-could be put to perhaps even more insidious uses: such theories provided the intellectual justification for segregated schools and housing, sexual sanctions, and ultimately (as Robert Gordon's paper made clear) for apartheid. The question is not the intrinsic merits of universalizing or relativizing ideologies, but the ways in which they were harnessed by colonial elites.

The struggle over whose knowledge was to prevail was unequal but not without its battles. Partha Chatterjee argues that Indian nationalist writers of the late 19th century conceded the realm of economics to British pundits, but claimed knowledge of how to organize the domestic and spiritual domains for themselves. On the other hand, even when colonial regimes were beginning to concede in the 1940 s and 1950 s that indigenous leaders were capable of running states and organizing economies, they did so in terms of "modernization" and "Westernization" - and a European-based concept of how states collected and used knowledge - - that denied the validity of African and Asian forms of knowledge perhaps even more than conservative forms of colonial rule. These issues are reminders that the question of knowledge and rule is always a political one. Such struggles are not just part of a wider battle, but a conflict over the nature of the battlefield itself.

\section{locating the tensions of empire: the problem of reproduction}

The weighty "ism" so often attached to "colonial" risks concealing the fact that the apparatuses by which conquering states ruled and by which they tried to impose their systems of 
order and knowledge were built by people who came from different classes, had conflicting interests, and as women and men conceptualized their own roles and goals in distinct ways. As David Arnold's conference presentation made clear, the most elementary form of colonial control-by the military - depended on soldiers who were simultaneously coerced and coercing, who enforced the will of the elite yet made demands themselves. In India, these agents of colonization often formed sexual relationships-including marriages-with indigenous women, and gave rise to a new group that came to be known as the Angloindians, whose ambiguous identity caused considerable worry to officials concerned with the social markers of British power. Similarly, the front-line troops of colonial commerce were in some contexts likely to establish close business and personal ties with local people, possibly creating still other interstitial and contradictory social categories.

The acuteness of this tension was revealed in the importance-in legislation, travel accounts, and literature - of regulating miscegenation, of defining the civil status and rights of Angloindians, "coloureds," "métis," and other socially or racially ambiguous groups. For people who were comparatively few in number, on the whole poor in wealth and in connections to the elites of conquered or conquering society, they received extraordinary attention.

Why was the ambiguous identity of colonizing populations the site of such tension in colonial regimes in the late 19th century? And why, too, especially in the 20th century, did colonial regimes also become obsessed with the sexual and family lives of the people they colonized? The two questions come together, as part of the single analytic field embracing colony and metropole, colonizer and colonized. Colonial regimes faced-in different times and in different ways-the problem not just of reproducing people, but of reproducing ways of life and forms of power.

Such concerns were historically contingent. In the 18 th century, the slave plantations of the West Indies reproduced their labor force by massive importations from Africa. Yet it was this form of reproduction - the violence of slave raids and the horrors of transportation - that gave the most vivid symbolism to the antislavery movement in 19th-century Europe and, later, to critiques of African societies for their continued involvement in slaving. Still later, the argument that forced labor prevented both demographic reproduction and the reproduction and extension of market relations became a key way in which European powers tried to distinguish the "moral" form of colonization that they practiced from the depredations of King Leopold's Congo. And in the 1930s and 1940s, when British and French officials began to have doubts about the system of migrant labor that was by then widespread, they again made an argument about demographic and cultural reproduction: migrancy reproduced the wrong kind of labor. Employing men for short periods and keeping their families in villages meant that, over time, generations of workers could not be acculturated to industrial discipline and contemporary European ideas about nutrition and sanitation.

At different times, colonial regimes had to come to grips with how people-colonizers and colonized alike-reproduced themselves (in families that lived together, as part of migration, through enslavement, through temporary sexual relations), where they did so (in villages, controlled housing projects, or squatter settlements), with whom (through race and class-specific unions or miscegenation), under whose eyes (the prying company manager or the medical professional), and with what degree of success.

What emerges most strikingly from the discussion of these issues is that race, class, and gender appear as moving categories, whose political saliencies shift in relation to one another. Verena Stolcke argued against the "add gender and stir" approach that brings in gender as yet another analytic dimension, while basically holding the others constant. Stoler contended that we cannot really explain how racial boundaries and class distinctions are secured without understanding how they are constituted in gender terms. Her paper, for example, shows that the protection and confinement of European women was not merely a symbol of white male rule. These women became the excuse for-and custodians of-racial distinctions that took the 
form of class-specific prescriptions for bourgeois respectability and sexual "normalcy." Medical discourse on the danger of physical contagion via colonized women slipped into a discourse on cultural and moral contamination and as such placed adherence to respectability and safeguards against racial degeneracy as imperatives of white rule.

If sexual behavior could specify the contents of "Europeanness," it could also define what was distinctly indigenous in the eyes of colonized people themselves. Partha Chatterjee has described a discussion among Indian men about Indian women that was in actuality a discussion about culture and national identity. He argues that in compartmentalizing the domestic, nationalist intellectuals distanced themselves not only from British rulers, but from the large majority of Indians. Stoler discusses sexuality in quite a different way: discourse about sex was not necessarily metaphoric: sex was about sex-and also about its consequences. Together, the two perspectives underscore the importance of struggles over personal and political identities in the colonial encounter, and of the multiplicity of consciousnesses-more complex than the dichotomy of colonizer and colonized - that confronted and transformed each other.

The domestic arrangements of colonized workers as well as colonial agents were constantly subject to reexamination as imperial thinkers thought out the relationship between subversion and sex. Policy makers fantasized about what people did at night and thus alternately saw prostitution, concubinage, and "healthy conjugal sex" as the basis on which colonial authority might be secured or irreparably undermined.

Sexuality was tied to politics at several levels and in numerous ways: even though shuttling men between male-only hostels at the workplace and family life in the village was a means of cheaply reproducing a labor force, such migratory patterns could also be seen to foster social disorder and political dissonance, while stable family life was seen as a way of depoliticizing the malcontent. Family ideology and political agendas are repeatedly linked by European administrators in Africa, Mau-Mau rebels, Malay officials, Sumatra's Dutch planters and subordinate whites. In the early 1930s, "extremist agitation" on Sumatra's estates was countered in part by the selective dismissal of its bachelor elements and by the encouragement of gezinvorming (family formation); 15 years later, British and French officials in Africa, challenged by a wave of protest in cities and mine towns, began to see stabilizing the family life of wage laborers as a solution to urban disorder.

Anticolonial movements had their own discourse on the family. Just as Partha Chatterjee showed the domestic domain to be a site of resistance to British rule among Indian intellectuals, Luise White discussed a dialogue about domesticity among largely illiterate rebels in the forests of Kenya in the 1950s. The argument among colonial officials about the costs and consequences of domesticating African reproductive practices was echoed among the guerillas, who were engaged in their own dialogue about what kind of people they wished to reproduce. What political intrigues might sexual promiscuity encourage, and what subversions might stable family life arrest? Tensions over what colonized people did by night were intimately tied to the daytime structures of colonial domination and to the psychological premises on which that authority was seen to rest.

But this was not always the case: colonial regimes divided families, quartered off regions of reproduction from the sites of production (as in South Africa) as often as they attempted to glue them back together. Why was sexuality so politicized under certain colonial conditions and not others? Why did family organization become so central at certain moments of economic restructuring and political crisis and elsewhere remain ignored?

Not only were sexuality, race, and class tied together, but all were linked to metropolitan visions and projects. For the most part, students of imperialism have discussed class issues in two ways: through the examination of accumulation by metropolitan capitalist classes (sometimes in conflict with capitalist classes that had taken root in colonial societies), and through analysis of the nature of class formation that capitalist penetration set off among indigenous peoples. But class impinged in the making of empire in other ways: constraining who came to 
the colonies, what class visions they harbored, what features of European class culture were selectively reworked by French civil servants in Algeria, by British planters in Malaya, by Dutch underlings on Sumatra's estates-and ultimately how racial boundaries were maintained.

In turn-of-the century East Africa, the British ysed a vocabulary to describe Africans remarkably like that used at home to describe the lowest elements of the class order, "the residuum," the degraded class of criminals and casual laborers of Victorian cities. Only no respectable working class existed between the African residuum and the Arab, Indian, and European middle and upper classes. Yet as John Comaroff shows here, the class baggage missionaries brought with them to South Africa in the mid-19th century was more complex than the language with which the top described the bottom. The class positioning of missionaries on the "social margins" of bourgeois Britain led them to an idealization of rural peasant life that in turn constrained their perceptions of the possibilities for African workers and put them in conflict with dominant factions of the colonial elite. Similarly, Randall Packard's analysis of medical discourse on native African reserves again reveals a bucolic vision, arising from a European experience, not an African one. The point is that the industrial restructuring of class relations in Europe resonated in the social engineering of empire in subliminal visions as well as concrete policy.

However important class origins and class projects are, so too are the dynamics of class relations in the colony itself. Stoler and Arnold discussed the elaboration of distinctions among colonizers, and how different modes of interacting with indigenous peoples-including sexual relations-both marked such distinctions and became tension-laden arenas for the contestation of status, autonomy, and control within the white population. The question was raised in discussion of whether protest and nationalist movements brought colonizing populations together, revitalizing a colonizer/colonized dichotomy that had softened or splintered when colonizers were more self-absorbed. Yet the opposite could happen too. After 1870, as Arnold pointed out, the Indian nationalist movement protested the conduct and role of low-ranking British employees, and top officials were often willing to sacrifice their subordinates in the name of stability. ${ }^{4}$ And as Jacques Marseille showed, when the cost of colonial wars began to be measured against the profits of colonial business, French capital was quicker than othersfrom white settlers to socialist reformers and imperial sentimentalists-to look for alternatives to the continued defense of overseas France.

This brings us back to the question of the state itself--and the colonial state in particular. The modern state did not have a pristinely metropolitan existence that then got transported, in however complex a way, to the colonies. States like France and Britain-not to mention Spain and Portugal in an earlier epoch - came to have national identities, national treasures, and national policies in relation to colonial ventures, in Ireland, the Americas, and elsewhere. The "imagined community" that was, for example, England was imagined in relation to Ireland and Scotland, to Jamaica and the North American colonies, as well as in relation to Spain and France. ${ }^{5}$ The opposite side of the social construction and the maintenance of the otherness of "the other" in the colonies-a point emphasized throughout our conference-was the social construction and the maintenance of national identity in the metropoles.

In turn, the circuit of personnel around empires-as high- and low-ranking civil servants moved from Martinique to Chad, as cotton merchants went from Uganda to India, and as prime ministers attended to crisis from the Transvaal to Tasmania-grounded the idea of empire in global experience. That in turn meant, as Partha Chatterjee put it, that the very nature of the colonial enterprise and whom it benefitted, was the site of the tension of empire, as in colony after colony Europeans confronted their own alienness within the very empires they were creating.

The meaning of this confrontation emerged with force in the 19th century as Europeans brought their universalizing ideologies to distant parts of the world. Tension opened up in the heart of such ideological constructs. As Michel-Rolph Trouillot showed, the proponents of free 
labor inside and outside the British Colonial Office had to face, as they tried to implement their crucial experiment in transforming slave into wage labor from the 1830s onward, the fact that ex-slaves in parts of the West Indies had their own ideas about labor and kept themselves at a distance from estate work. The "peasantry" that emerged was so alien to British expectations that it could not be acknowledged, and the relationship between free labor ideology and developments on the ground were expressed by a loud silence. Only at century's end, when much of the Caribbean had ceased to be a significant site of production, did the self-sustaining, lowcost, orderly nature of peasant production become accepted among policy markers; but in the meantime - and even more dramatically after the revolt of ex-slaves in Jamaica in 1865—race had been evoked to explain why blacks had not responded to the "free" market as neoclassical economists and abolitionists had insisted they would (see also Cooper, this volume). In practice, colonial confrontations were constantly giving rise to "special conditions," as Chatterjee put it, that stood in the way of universal progress.

The overarching tension was between what colonialism was and what colonial regimes did, between the fact of rule and its economic and social consequences. The tension manifested itself between Comaroff's missionaries-with their clear vision of Christian colonization-and the economy that settlers, mineowners, and officials of South Africa created. It also manifested itself in the idea of indirect rule which became dogma in Great Britain in the 1920s: the doctrine of ruling through indigenous political structures and customary practices-however artificial it was in reality-implied that if one was to rule well, one should not do too much with one's rule. The relationship of ruling and acting changed again, in French as well as British colonies, in the 1940s, as imperial powers sought to make their empires more productive and orderly and to justify their rule on the basis of the "development" they were bringing to colonial peoples. But by the 1950s, as the centrally directed programs for development encountered numerous obstacles and stimulated more opposition than they deflected, it became clear that if European powers hoped to see economic and social change result from their rule, they could not rule at all.

\section{dynamics of empire}

At some times, the issue of how colonized people reproduced themselves mattered; at others it did not. How can such debates be connected to economic trends, to patterns of conquest and rebellion? Did the discourses of urban planners, of agronomists, of medical professionals, and of educators undergo transitions at similar time periods or go through similar sequences even if on different dates? ${ }^{6}$ Did colonial regimes draw on models--such as the experience of Hispanic colonization in earlier centuries-in figuring out how they should constitute, symbolize, and justify their rule. And did different powers draw on each others' models and try to develop in international conferences and other fora a transnational consensus on how colonial powers should behave? Did the visions of rule of particular groups-missionaries, settlers-or of the rulers of particular nations ever become coherent enough to constitute a specific "colonialism," competing with rival "colonialisms," and perhaps giving rise at a critical conjuncture to new consensuses or new rivalries?

We had hoped that holding our papers next to each other would allow for a precise discussion of questions about periodization. Within limits, parallels were revealed. In regard to Africa, for example, distinct groups of professional experts changed their conceptions of indigenous social life in rough synchronization: the vision of both French and British labor inspectors of the kind of workplace they wanted altered in close relationship to the discourse about housing and sexuality in other "technical" departments and in close relationship to a discourse about order and disorder among political officials.

Yet similar discussions could come to differing conclusions. South African policy makers debated labor and health issues in the mid-1940s in terms not far removed from those applied 
to French and British Africa, but after 1948 decided instead to build up a coercive apparatus to reinforce migration. Health officials there did not break so strongly with the myth of healthy rural life that was being torn down elsewhere. In international fora, South African social policy went from positive model to the epitome of reactionary racism: its experts on African labor, nutrition, welfare, and health were not listened to in the 1950s as they were in the 1940s.

Sequences could reveal common themes even when chronologies diverged. The post-Mutiny discussion of order in India-with its implications that white society had to make itself more distant, more controlling, more respectable in relation to indigenous society-appeared around 60 years before comparable discussions emerged in British Malaya or the Netherlands Indies. And both discussions reveal a crucial point to any analysis of periodicity and causation: some of the most important initiatives in recoding knowledge and redefining categories took place in response to the actions of indigenous peoples expressed in different forms: from flashes of violence to the development of nationalist movements to inchoate resistance against attempts to reorganize labor or agriculture. At the very moment when British officials-their Victorian images of class society in mind-were trying to make slaves and peasants into a wageearning class in some of their newly conquered colonies of Africa, they were giving up such ambitions in the older colonies in the West Indies, thanks to years of frustrating experience (compare the papers of Trouillot and Cooper). All this suggests that a single, straightforward periodization of colonial history is likely to remain an elusive goal, precisely because the colonized world was experiencing not one historical dynamic but the intersection of multiple dynamics, of multiple historicities.

Much of the conference discussion, however, focused on a longer time span, and followed from challenges, coming from Sidney Mintz, Talal Asad, Verena Stolcke, and Michel-Rolph Trouillot, to consider the formative experience of earlier eras-the techniques of rule that the Hispanic empires passed on or the long experience that planters, officials, and slaves in the West Indies had acquired with each other when the 19th century began-on the shape of 19thcentury colonialism. The discussion nonetheless reinforced the sense that break points of global significance existed within the history of colonialism, and the longer view helped to clarify what they were about.

The main foci of discussion were, first, two break points in the advance of imperialism: the early 19th century - when the debate over slavery brought the new universalist discourses on economy and state into the colonies-and the end of that century-when a newly interventionist imperialism promised to transform not only sovereignty but social structures in conquered lands. Second, participants debated the importance and causes of key points in the retreat of colonial rule in the 20th century: World War I, the depression of the 1930s, and the era of failed reform in the 1940s and 1950s.

All these points draw attention to imperialism as viewed from the center but not necessarily determined at the center, for the transition points in European policies and discourses reflected encounters in the colonies themselves. Colonial rule as such could be attacked and defended, by Hobson, Gandhi, and Lugard, by Fanon and de Gaulle, but the global focus should be balanced by attention to the myriad debates over political and social issues that overlapped the colonial question, by understanding of the rhythms of intersecting histories, and by awareness of the gaps between policy and practice, between coherent images and inchoate situations.

The change in European discourse on colonies in the early 19th century was not the emergence of new forms of production-the slave plantation was still the height of managerial and technological sophistication-but of a new kind of politics pioneered in the campaign against the slave trade and slavery. Under British pressure, the world powers, at congresses and in treaties, entered a dialogue that was universalistic, international, and moralistic. Enslavement of non-European peoples was condemned in the name of a universal definition of free labor that transcended the moral vision of any one religion or any one state, raising the possibility of 
international standards for imperial behavior, of European powers critiquing their own or each other's past and present behavior and the practices of non-Europeans.?

The "new" imperialism of the last quarter of the century was no less coercive and brutal than the old. Yet Europeans were taking pains to reassure each other that their coercion and brutality were not frank attempts at extraction-as in the days of looting, pillaging, and slave raidingbut attempts to build structures capable of reproducing and extending themselves: stable government replacing the violent, conflictual tyrannies of indigenous polities, orderly commerce and wage labor replacing the chaos of slaving and raiding, a complex structuring of group boundaries, racial identities, and permissible forms of sexual and social interaction replacing the fluidity of relationships of an earlier age. The "embourgeoisement" of imperialism in the late 19th century enhanced expectations of hard work, sexual restraint, and racial distancing among the colonizing agents, while opening a more intimate domain for condemnation and reform in the lives of the colonized. When other European powers condemned the atrocities in King Leopold's Congo, they signaled that colonizers could deviate only so far from the norms. In their own dominions in Southeast Asia, John Butcher's paper revealed, British officials at the end of the century began to question such successful forms of revenue raising as gambling farms, which now appeared inconsistent with the need for the orderly expansion of commerce and labor power and the needed transformation of indigenous culture.

The violence of this form of colonization entailed, as Talal Asad expressed it, monumental destruction at every level, precisely because it attempted to reorganize not only the polity, but social relations, economic structures, and values. It was not just the violence of pillage, but the violence of self-conscious and self-righteous transformation of social life. And its destructiveness was not just a question of conquest but of law: an attempt to redefine norms as well as practices. Colonial law never embodied a purely class- or market-based vision of social order. As Joan Vincent demonstrated, the commercial law of Uganda was racially coded: officials did not wait for Africans, Asians, and Europeans to fall into their expected economic roles, but legislated what kinds of activities each category could engage in; the law defined permissible activities by gender as well.

Projects were not necessarily successful-the very intimacy of the domain they sought to penetrate made them frequently resistant to the blunt instrument of colonial bureaucracies. Moreover, as Chatterjee pointed out, the fact that the modern state, with its projects as well as its organizational instruments, was entering more and more domains of social life tended to turn conflicts over a variety of social issues into conflict over the state itself.

The crisis points of the 20th century remain subjects of controversy, in regard to timing as well as causation: Michael Adas' paper on World War I allowed us to discuss whether the crisis of European confidence in its "civilizing mission" was provoked by the shock of the war in Europe or by the ability of colonial peoples to resist European goals of social reorganization and economic productiveness. At the same time, the involvement of colonial peoples, as soldiers and otherwise, in a world war led to anxiety-expressed as the fear of pan-Islamic or panAfrica movements-that political movements in the colonies might make an analogous leap to the global level. One can interpret the British shift to the doctrine of indirect rule in the 1920s as an attempt to insist that Africans should exist only in "local" and "traditional" space and not in "world" or "political" space; nationalist movements in India, by that time, were far too powerful to be so confined.

In the war's aftermath, calls in Britain and France for another attempt to reinvigorate the drive to remake colonial societies clearly failed to gain support at home. Yet at this very time, as Atran shows, the realpolitik of British leaders and the progressivist vision of leftist Zionists created a curious alliance for a new colonial initiative in Palestine, in which Jewish settlers, as "surrogates" of European directed progress, would liberate backward Arabs from their repressive elites and create a society that would simultaneously serve social progress and British interests. 
The crises of depression in the 1930s and world war in the 1940s simultaneously increased European nations' need to mobilize colonial resources and shook their confidence in their ability to control the fate of other peoples, a point that many activists in the colonies-from nationalists to the leaders of local and religious resistance-understood. Much remains to be learned about the movements and conflicts that reshaped the world after depression and war, and set off the process of decolonization, with its hopes and its limitations. For the scholar seeking to understand the cultural politics of colonialism and its continued impact on ex-colonial states and world politics, unravelling this period remains extremely important. Which colonialism was shaping what practices?

The colonialism that collapsed in much of Africa and Asia was colonialism in its most missionizing, reforming, and arrogantly interventionist phase. In the 1940s, France and Britain tried to make the idea of social and economic development into the heart of a renewal of an imperial mission. Colonial powers-armed with scientific knowledge, modern organizational techniques, and capital—would lead the drive toward more efficient production, scientific agriculture, modernist city planning, Western education, and modern medicine. These policies, as Cooper argues in this volume, implied a changed conception of the distinctiveness of colonized people: their "cultures" did not so much define their unique ways of life as constitute an obstacle to their modern future. On the ground, the new goals were as unrealizable as those of late 19th-century imperialism. One can even argue that the end of empire was hastened by the reformist drive itself: state-controlled development projects, making new demands on people, reallocating resources and access to power, and creating expectations on which colonial authorities could not deliver, fostered the resistance such policies were intended to avoid and focused it on the question of control of the state.

In any case, the developmentalist rationale for postwar imperialism-and its failure to contain fundamental challenges to European rule-brought to the fore the underlying tension between the European attempt to place its own civilization at the center of a universalistic vision of global progress and the particularistic nature of colonial rule itself. The colonizers' culture represented rule, not just modernity. Articulating a European mission to develop implied giving recognition to those colonial subjects who met European standards in their economic, social, and political behavior, while consigning those who did not to the dustbin of backwardness. At the same time, the emphasis on applying the universal laws of social science to colonial peoples left less and less room for the wise white representative of European civilization, who knew his natives and who embodied "civilization" in his very being. Postwar imperial ideologies remained and remain progressivist and arrogantly ethnocentric; they did not and do not remain specifically colonial.

\section{conclusion}

Toward the end of our discussions, Michel-Rolph Trouillot asked, what sort of ethnography did our deliberations call for? What sorts of texts were generated, who read them, and to whom did they matter? Implicitly, the questions raised in all papers called for ethnographic reconstructions - using written texts as well as biographical and interview material —of colonial bureaucracies, of medical institutions, of schools. We are confronted with the obvious fact that every document in a colonial archive-no matter how ignorant its author was of indigenous society or how unimportant his ideas were to future policy-is layered with the received account of earlier events and the cultural semantics of a political moment. As David Prochaska and other participants noted, we cannot just do colonial history based on our given sources; what constitutes the archive itself, what is excluded from it, what nomenclatures signal at certain times are themselves internal to, and the very substance of, the cultural politics of colonial rule. For example, debates over "white pauperism" in the Netherlands Indies in the 1890 s were 
produced by, and most important, directed toward a very different social category than an apparently similar debate in British India on white pauperism 20 years earlier. Our ethnographies of empire must find some balance between the universalizing idioms of rule and the cultural specificity of their content.

In addition, we need to confront the more elusive methodological problem of connecting what was written to what was said and to what was done, of exploring the relationship of the language of the written documents to the language of the people who were the objects of bureaucracy but the subjects of their own lives. As we move closer to understanding how colonial regimes constructed their categories of authority, we need to remain attentive to what contemporary anthropologists are doing best, identifying how these classifications were appropriated and reworked by colonized women and men themselves.

We end up with a point raised by John Comaroff in relationship at the mission situation of the mid-19th century. How much of the terms in which missionaries discussed the self and its connection to politics, economic choice, and social relationships became internalized, appearing in different forms later on, in the languages and social relationships of indigenous peoples? One can ask the same question about the "experts" on health and industrial relations, about the architects of housing policy and family allowances: what penetrated, what resonated, and what was ignored, denied, or reshaped? And to what extent did the scientific arrogance of mid-20th century colonialism create attachments and shared perceptions with international bodies, international educational networks, international aid agencies, and shape how postcolonial polities could and could not define social issues? ${ }^{\mathrm{B}}$ Such concerns call for more ethnographic work on late colonial and present-day societies: looking, for example, at African doctors not as part of an African elite-as is fairly often done-but as part of an international medical community, in which questions of knowledge and outlook cannot be separated from questions of power.

At the same time, the conflicting visions of rule within colonial regimes could also open up space within which colonized people could find room to challenge parts of the colonial edifice, to see not only its cracks but its underlying structure. Seeking new ways of thinking about the anthropology and history of colonial states and colonizing populations will sharpen our perspectives on the confrontation of multiple ideologies and consciousnesses, helping us to examine how people mobilized different sorts of material and cultural resources in contesting what empires did and the legitimacy of empire itself. However much we recognize that the idea of indigenous "responses" to colonialism is insufficient, it remains difficult to keep the dynamics of colonizer and colonized in view at the same time, just as it is difficult to assess how much of the colonization process was shaped by the colonized as well as by the colonizers. The colonial encounter entailed struggles over differing forms of knowledge, over group boundaries, over moralities, over the intimate details of work and life. Colonial governors and missionaries, settlers and technocrats, cast their gaze across the globe, but the question remains: to what extent were their visions clear or powerful enough to remake it?

\section{notes}

'Not all participants were able to include their papers in this volume. In addition to the papers collected here, the following were also presented at the conference: Bernard Cohn, "The Anthropology of a Colonial State and Its Forms of Knowledge"; David Arnold, "The Army, Poor Whites, and Social Stratification in Colonial India"; Verena Stolcke, "The Slavery Period and Its Influence on Household Structure and the Family: Jamaica, Cuba, and Brazil"; Robert Gordon, "Radcliffe-Brown in South Africa and the Origins of the Intellectual Critique of Apartheid"; John Butcher, "Revenue, Morality, and the Gambling Farms in the Federated Malay States"; Joan Vincent, "Changing the Colonial Office Mind: Producers and Traders in Uganda, 1908-38"; David Prochaska, "The Archive of Algérie Imaginaire"; Luise White, "Separating the Men from the Boys: Colonial Constructions of Gender, Sexuality, and Terrorism in Central Kenya, 19391959"; Jacques Marseille, "'Gauche,' 'droite' et fait colonial en France, des années 1880 aux années 1960"; and Michael Adas, "The Great War and the Decline of the Civilizing Mission." Talal Asad and 
Sidney Mintz served as discussants. Nancy Hunt was rapporteur. The editors would like to thank all participants for their papers and contributions to discussion-on which this introduction draws heavily-as well as the Wenner-Gren Foundation for its support. In addition, John Comaroff and Randall Packard provided helpful critiques of an earlier draft of the introduction.

${ }^{2}$ This is not to suggest that racism was not central to European nation-state formation as well. See Balibar (1989) who argues explicitly that racism was fundamental to the definition of European citizenship.

${ }^{3}$ See George Mosse's Nationalism and Sexuality (1985) for a discussion of how these terms came together in a European context. These comments on 19th-century colonization do not belie the difficulty of thinking about old as well as new colonies or of considering situations, notably in the Americas, where elites of European origin were breaking away from their metropoles and establishing new and at times ambivalent connections between their European and American identities.

${ }^{4}$ Conflict among whites also followed conflict with blacks in South Africa: a powerful African mine workers' strike of 1920 was followed in 1922 by a strike of white miners (partly concerned with perceived gains achieved by blacks), which became a violent rebellion including much of the poor, rural, Afrikaans-speaking white population of the mining region. The revolt was ruthlessly repressed by mine owners and the state.

${ }^{5}$ See Anderson (1983) for the relationship of imagination and nationalism and Corrigan and Sayers (1985) on the construction of identity in European states.

${ }^{6}$ The kinds of questions raised about anthropology in the pioneering collection of Asad (1973) need to be explored in relation to other disciplines, such as health and development economics, and the linkages among these fields explored.

TThe Congress of Vienna of 1815 can be taken as a marker of the arrival of this new discourse: the European powers collectively condemned the slave trade as evil. After that, it is hard to find a principled European defense of the slave trade; states could only allow their subjects to continue in it by indifference or subterfuge. This subject, not surprisingly, has given rise to an enormous historical debate, briefly touched on here by Trouillot and Cooper and more systematically in Davis (1984).

${ }^{8}$ The anthropology of colonialism thus shades off into a critical anthropology of development.

references

Anderson, Benedict

1983 Imagined Communities: Reflections on the Origins and Spread of Nationalism. London: Verso.

Asad, Talal, ed.

1973 Anthropology and the Colonial Encounter. London: Ithaca Press.

Balibar, Etienne

1989 Le racisme: encore un universalisme. Mots (special issue on Racisme et antiracisme) 18:7-20.

Corrigan, Philip, and Derek Sayer

1985 The Great Arch: English State Formation as Cultural Revolution. Oxford: Blackwell.

Davis, David Brion

1984 Slavery and Human Progress. New York: Oxford University Press.

Mosse, George

1985 Nationalism and Sexuality: Respectability and Abnormal Sexuality in Modern Europe. New York: Fertig.

submitted 27 March 1989

accepted 6 July 1989 